June 2018

\title{
SRJ 100K Download Milestone
}

\author{
Mary C. Schutten \\ California State University - San Jose, mary.schutten@sjsu.edu
}

Follow this and additional works at: https://scholarworks.sjsu.edu/ischoolsrj

Part of the Archival Science Commons, Cataloging and Metadata Commons, Collection Development and Management Commons, Information Literacy Commons, Scholarly Communication Commons, and the Scholarly Publishing Commons

\section{Recommended Citation}

Schutten, M. C. (2018). SRJ 100K Download Milestone. School of Information Student Research Journal, 8(1). https://doi.org/10.31979/2575-2499.080102 Retrieved from https://scholarworks.sjsu.edu/ ischoolsrj/vol8/iss $1 / 2$

This article is brought to you by the open access Journals at SJSU ScholarWorks. It has been accepted for inclusion in School of Information Student Research Journal by an authorized administrator of SJSU ScholarWorks. For more information, please contact scholarworks@sjsu.edu. 


\title{
SRJ 100K Download Milestone
}

\begin{abstract}
About Author
Dr. Mary C. Schutten is Dean of the College of Applied Sciences and Arts (CASA) at San Jose 'State University (SJSU). Dr. Schutten joined CASA in 2015 from Grand Valley State University in Michigan, where she served as associate dean for students and curriculum within the College of Liberal Arts and Sciences and professor in Movement Sciences. A former NCAA coach, as well as middle and high school teacher, Dr. Schutten has published and presented for both academic and professional audiences.
\end{abstract}


On behalf of the College of Applied Sciences and Arts, I want to extend my congratulations to the entire staff of the Student Research Journal in the School of Information for reaching the milestone of 100,000 downloads of their high quality, student governed open source journal. These downloads span 189 countries, which dovetails with the college's commitment to global education experiences. Thank you for this good work. The journal is a significant accomplishment and, with over 80 graduate student papers published, the journal has given voice to the many exceptional students in our programs.

The Association of American Colleges and Universities, AACU, lists on their website various teaching and learning strategies that have been tested and shown to be beneficial for students from a variety of backgrounds. These practices are labeled as high impact educational practices or HIPS

(https://www.aacu.org/leap/hips). Among the listed practices, a reader would find student research, writing intensive courses, collaborative projects, culminating projects, and global learning. The Student Research Journal in the School of Information uses all of these practices which benefits students, university, and the global community. Congratulations to the entire journal editorial staff, Dr.

Anthony Bernier, advisor, and to Editor in Chief Holley Cornetto. Your scholarly efforts are a "best practice", they are HIP, and a key contributor to the success of students at SJSU. 